\title{
KOMUNITI MAPAN: \\ PENILAIAN TAHAP KEMAPANAN KOMUNITI ORANG ASLI TEMIAR DI NEGERI PERAK
}

\author{
Khairul Hisyam Bin Kamarudin ${ }^{1}$ \\ Jabatan Kejuruteraan Awam \\ Kolej Sains dan Teknologi \\ UTM City Campus, Kuala Lumpur, MALAYSIA \\ Ibrahim Bin Ngah ${ }^{2}$ \\ Jabatan Perancangan Bandar dan Wilayah \\ Fakulti Alam Bina \\ UTM Skudai, Johor, MALAYSIA
}

\section{Abstract \\ SUSTAINABLE COMMUNITY: \\ AN EVALUATION ON SUSTAINABILITY LEVEL OF ORANG ASLI TERMIAR COMMUNITY IN PERAK}

In the declaration of the Conference on Environment and Development at Rio de Janeiro 1992, the role of indigenous people in environmental management and development for achieving sustainability was recognized because of their knowledge and traditional practice. However, the value and traditional practices of the indigenous communities today has gradually disappeared due to pressure from modernization and influence of market economy, which penetrated them. The study examine the extent to which the knowledge and practice of the Orang Asli community comply with sustainable development principles and how their knowledge and practice could be used to derive a framework for sustainable development strategies of Orang Asli community. As an introduction, this article present an alternative thought on the concept and also suggestions on the characteristics of sustainable community. This study revealed that, sustainable community should be guided by a set of system which maintains the relationship of trinity; i.e. relationship between Man and his Creator, Man and Man, and Man and Environment. Eventually, this would help to attain balanced and sustained development economically, socially, environmentally and spiritually. Another part of the study involves an in-depth case study on the selected Orang Asli Temiar settlements in the state of Perak. Based on a case study of Orang Asli Temiar communities of Kampung Perjek and Kuala $\mathrm{Mu}$, the study evaluated the level of sustainability of the

\footnotetext{
${ }^{1}$ khisyam@citycampus.utm.my

2 Professor Madya Dr. Ibrahim boleh dihubungi di b-ibrahim@utm.my.
} 
community's base on the indicators formulated. Forty-five (45) indicators were finalized in a comprehensive manner covering economic, social and physical dimensions. These indicators were then categorized into behaviour, system and situational components. Fieldworks were conducted and the level of sustainability of each indicator was analyzed based on the information collected and index was used to measure the overall sustainability. This study shows variability of sustainability levels of each indicator. Findings from the first part of the analysis (sustainability level for each indicator) showed that only nine of the 16 behaviour indicators have achieved sustainability level. Under system category, only two out of 10 indicators achieved the level of sustainability and for indicators under state category, seven out of 19 indicators achieved the sustainability level. Meanwhile, for the index analysis (overall sustainability level of each dimension) it showed that the levels of sustainability were moderate for the social and physical/ecological indicators $(42.1 \%$ and $60.0 \%)$ and low for the economic indicators $(25.0 \%$ ). Based on the findings and discussions with the local community, this study suggests a framework for the sustainable development strategy which includes; (1) conserve or encourage continuation of current sustainable practices, (2) improve or change the unsustainable or low level of sustainable practices and (3) develop the potential of the area in a sustainable manner.

Keywords: Sustainable Development, Community, Indicator, Orang Asli, Strategy

\section{APA ITU KOMUNITI?}

Perkataan komuniti telah diberikan pelbagai tafsiran. Kamus Oxford mendefinisikan perkataan community sebagai satu kumpulan manusia yang tinggal dalam satu tempat; secara bersama dan mempunyai kepentingan. Manakala menurut kamus Longman, community ialah sekelompok manusia yang tinggal di dalam suatu kawasan yang sama; berkongsi kerakyatan atau agama atau mempunyai kesamaan dalam sesuatu keadaan. Definisi-definisi tersebut mengklasifikasikan dua elemen penting di dalam pembentukan komuniti iaitu kumpulan manusia yang tinggal di satu tempat yang sama dan berkongsi kepentingan.

Sekumpulan manusia yang hidup bersama sebagai satu komuniti pastinya akan menjalankan pelbagai aktiviti bagi kelangsungan hidup diri dan keluarga serta menambahbaik keadaan dalam komuniti. Oleh yang demikian, setiap komuniti memerlukan suatu sistem hidup yang mantap bagi mengurus serta mengawal organisasi kehidupan dan keperluan yang pelbagai daripada ahli-ahli di dalam komuniti supaya tidak berlaku perlanggaran terhadap hak individu lain serta untuk dijadikan asas bagi memandu tindakan komuniti supaya menghormati lingkungan batas alam semulajadi untuk kepentingan bersama. Dalam konteks ini, komuniti boleh dirumuskan sebagai sekumpulan manusia yang tinggal 
dalam satu kawasan yang sama, mempunyai sistem peraturan tersendiri dan institusi bagi membolehkan ahli-ahlinya hidup secara bersama.

\section{KONSEP KOMUNITI MAPAN}

Selepas terbitnya laporan oleh Suruhanjaya Brundtland pada tahun 1987 yang menjadi asas gagasan kepada pembangunan mapan, pelbagai usaha dijalankan bagi mengintepretasi konsep serta definisi yang umum tersebut menjangkau lapangan yang lebih luas sehingga kepada pembangunan komuniti luar bandar. Bahagian artikel ini menyediakan pandangan alternatif terhadap konsep komuniti mapan dengan harapan membuka ruang percambahan pemikiran mengenainya, dan bagaimana konsep komuniti mapan dapat diterjemah kepada realiti berdasarkan keperluan dan keadaan komuniti luar bandar yang berbeza. Konsep komuniti mapan lahir daripada kesedaran bahawa kelangsungan hidup manusia perlu diteruskán untuk generasi seterusnya dan kepentingan jangka panjang ini bergantung kepada cara komuniti hari ini mengurus, membangun serta mengguna secara mapan sumber-sumber yang terdapat disekitar lingkungan hidup mereka (Khairul Hisyam Kamarudin dan Ibrahim Ngah, 2004).

Perbincangan mengenai komuniti mapan juga tidak dapat lari dari membicarakan tiga dimensi yang menjadi teras kepada pembangunan mapan dan saling kuat terikat antara satu sama lainnya iaitu ekonomi, sosial dan alam sekitar (Moffatt, 1996; Hjorth dan Bagheri, 2006). Idea perancangan komuniti mapan oleh Ibrahim Ngah (2003) misalnya, menggabungkan pengertian pembangunan mapan dan komuniti secara bersepandu di mana beliar telah merumuskan komuniti mapan sebagai komuniti yang menerimapakai cara hidup dan jalan pembangunan yang menghormati dan bertindak dalam lingkungan batas alam semulajadi.

Untuk membentuk komuniti yang dapat menghormati dan bertindak di dalam lingkungan batas yang mampu ditampung alam semulajadi, sistem hidup komuniti perlu dikawal oleh suatu struktur perundangan yang mantap, dapat difahami dan dipatuhi setiap ahlinya. Justeru, konsep komuniti mapan yang ditekankan oleh kajian ini memerlukan tindakan bersepadu berteraskan kekuatan pertalian antara tiga dimensi iaitu:

1. MANUSIA DENGAN MANUSIA - kemapanan dalam aspek sosial, ekonomi dan politik

2. MANUSIA DENGAN ALAM - kemapanan dalam aspek ekologi 
3. MANUSIA DENGAN PENCIPTA - kemapanan dalam aspek kesedaran adanya tuhan (god consciousness)

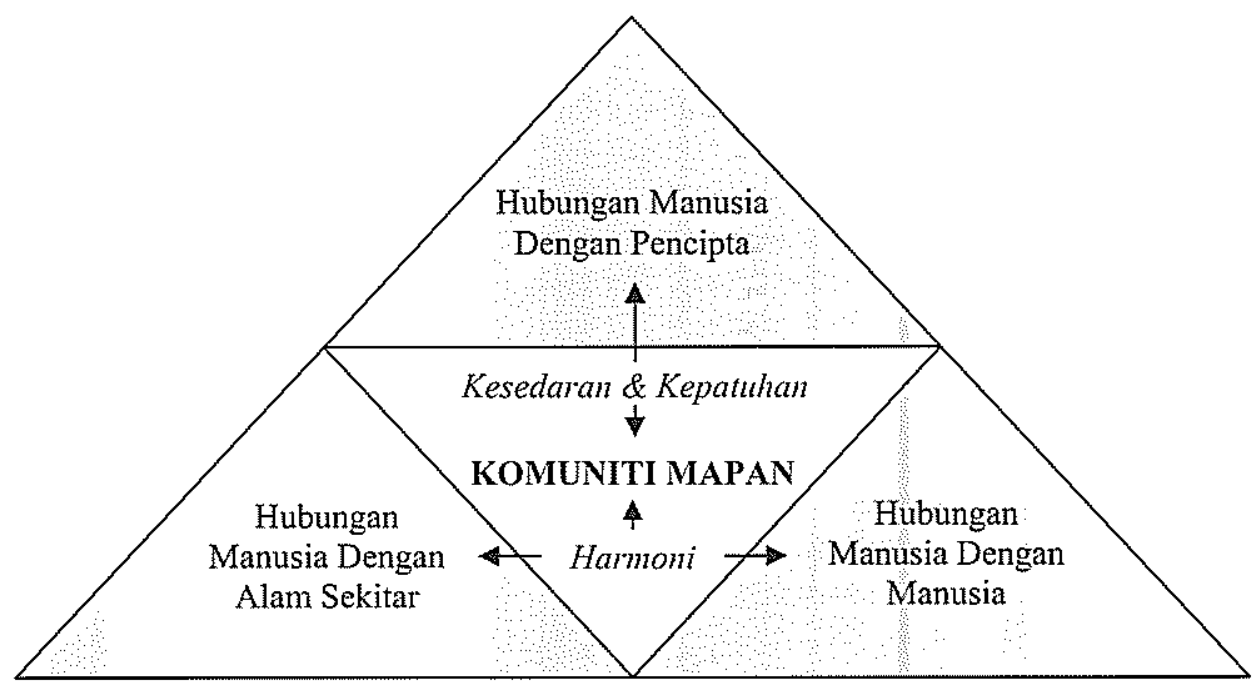

Rajah 1: Cadangan konsep komuniti mapan

Cadangan penulis pada Rajah $I$ di atas bertujuan memperluaskan rangka kefahaman berkenaan komuniti mapan dengan dengan cadangan memasukkan hubungan ketuhanan sebagai salah satu dimensi yang menunjangi konsep tersebut selain hubungan sesama manusia (berkaitan aspek ekonomi, sosial dan politik) dan hubungan dengan alam sekitar (berkaitan aspek ekologi). Jika sebelum ini perancangan pembangunan luar bandar yang mapan dapat menerima integrasi nilai kerohanian sebagaimana dijelaskan pada Doktrin Perancangan dan Pembangunan Sejagat (Zainuddin Muhammad, 1997), adalah tidak mustahil penerapan nilai yang serupa sebagaimana cadangan konsep komuniti mapan luar bandar ini mampu dilaksanakan. Sewajarnya tindakan merancang dan membentuk sistem hidup komuniti yang mantap dan komprehensif memerlukan kefahaman terhadap pencipta sebagai asas mencapai kesejahteraan bagi kehidupan yang berterusan.

Sebagai rumusan, komuniti mapan adalah komuniti yang mempunyai satu sistem hidup yang komprehensif berteraskan ilmu dan budaya bagi mendokong prinsip dan amalan kemapanan. Sistem hidup tersebut mestilah mempunyai interaksi seimbang dan bersepadu antara manusia dengan manusia; manusia dengan alam dan manusia dengan pencipta (Khairul Hisyam Kamarudin dan 
Ibrahim Ngah, 2005). Daripada cadangan konsep komuniti mapan juga, penulis turut mencadangkan ciri-ciri yang perlu terdapat bagi sesebuah komuniti mapan sebagaimana dijelaskan pada Jadual 1.

Jadual 1: Cadangan ciri-ciri komuniti mapan

\begin{tabular}{|c|c|c|}
\hline & i Komuniti Mapan & irim-Ciri \\
\hline 1 & 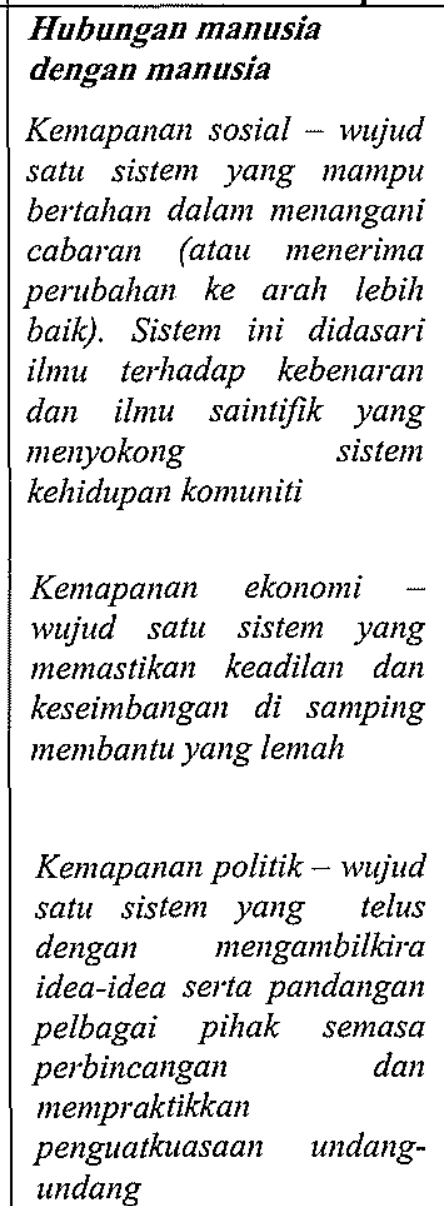 & $\begin{array}{l}\text { Sosial } \\
\text { - Sistem yang menjana kesinambungan generasi } \\
\text { - Sistem yang menjaga kualiti manusia } \\
\text { Sistem yang menjaga perhubungan lelaki dan } \\
\text { wanita } \\
\text { o Institusi perkahwinan } \\
\text { o Tatacara bersosial/pergaulan } \\
\text { o Institusi keluarga } \\
\text { - Sistem yang mengawal kemudaratan akibat } \\
\text { kepincangan hubungan bersama } \\
\text { o Institusi kehakiman/pelaksana hukum } \\
\text { Ekonomi } \\
\text { - Sistem yang menjamin keadilan dalam } \\
\text { komuniti } \\
\text { - Sistem yang menjamin kesamaan peluang } \\
\text { Sistem yang menjamin kesinambungan di } \\
\text { dalam agihan hasil/kekayaan } \\
\text { Wujud mekanisma khusus bagi memastikan } \\
\text { keberkesanan terhadap aktiviti ekonomi } \\
\text { Sistem membantu yang lemah } \\
\text { Politik } \\
\text { - Sistem yang menggalakkan penglibatan/ } \\
\text { penyertaan ahli dalam komuniti memberikan } \\
\text { idea } \\
\text { Sistem yang menampakkan kepatuhan kepada } \\
\text { pemimpin yang dilantik selagi berlaku adil } \\
\text { Sistem penguatkuasaan peraturan dan undang- } \\
\text { undang }\end{array}$ \\
\hline
\end{tabular}


Jadual 1: Sambungan...

\begin{tabular}{|c|c|c|}
\hline & Kor & Ciri \\
\hline 2 & $\begin{array}{l}\text { Hubungan manusia } \\
\text { dengan alam sekitar } \\
\text { Kemapanan ekologi - } \\
\text { wujud satu sistem yang } \\
\text { mampu menguatkuasakan } \\
\text { tindakan terhadap } \\
\text { penggantian sumber, kitar } \\
\text { semula, rawatan sisa dan } \\
\text { pemeliharaan stmber di } \\
\text { samping terdapat } \\
\text { mekanisma institusi yang } \\
\text { mengawal ristem } \\
\text { hubungan ini }\end{array}$ & $\begin{array}{l}\text { Ekologi } \\
\text { - Sistem yang menjamin kesamaan agihan } \\
\text { sumber } \\
\text { - Sistem yang memastikan pemeliharaan } \\
\text { sumber untuk generasi akan datang } \\
\text { - Sistem yang memastikan pemuliharaan } \\
\text { sumber selepas diguna } \\
\text { - Sistem bagi penggantian sumber terutama } \\
\text { yang boleh diperbaharui } \\
\text { Sistem yang mempraktikkan prinsip } 5 \mathrm{R} \text { dan } \\
\text { penjimatan } \\
\text { Sistem khusus bagi rawatan sisa hasil } \\
\text { penggunaan sumber alam }\end{array}$ \\
\hline & $\begin{array}{l}\text { Hubungan manusia } \\
\text { dengan pencipta } \\
\text { Suatu sistem yang } \\
\text { memerlukan ahli komtmiti } \\
\text { sedar adanya tuhan/kuasa } \\
\text { yang mencipta alam }\end{array}$ & $\begin{array}{l}\text { Kerohanian/Spiritual } \\
\text { - Sistem yang mewujudkan kepatuhan kepada } \\
\text { pencipta } \\
\text { - Sistem yang menggalakkan amalan/etika yang } \\
\text { baik dan melarang amalan/etika yang buruk } \\
\text { - Sistem yang memantapkan kekuatan dan } \\
\text { kesucian dalaman diri } \\
\text { - Sistem yang menggalakkan kesederhanaan } \\
\text { hidup }\end{array}$ \\
\hline
\end{tabular}

\section{KEPERLUAN KAJIAN KEMAPANAN KOMUNITI ORANG ASLI}

Di dalam deklarasi Persidangan bagi Alam Sekitar dan Pembangunan di Rio de Janeiro 1992, peranan penduduk pribumi di dalam pengurusan alam sekitar dan pembangunan untuk mencapai kemapanan hasil amalan dan ilmu pengetahuan tradisional mereka telah disentuh secara khusus di dalam Prinsip ke-22 deklarasi iaitu:

Indigenous people and their communities and other local communities, have a vital role in environmental management and development because of their knowledge and traditional practices. States should recognize and duly support their identity, culture and interest and enable their effective participation in the achievement on sustainable development

(Earth Summit, 1992: 13) 
Banyak penyelidikan yang dibuat menunjukkan terdapat peranan penting dan sumbangan ilmu pengetahuan pribumi dan amalan-amalan yang menjurus kepada kemapanan (Loomis, 2000; Musiiwa, 2002; Pulido dan Bocco, 2003; Karjala dan Dewhurst, 2003). Bagaimanapun, nilai dan amalan tradisional komuniti tersebut hari ini dilihat mulai lenyap disebabkan tekanan oleh arus pemodenan dan penerimaan meluas sistem ekonomi bebas yang berasaskan pasaran (laissez-fair economy) yang mereka sendiri dilihat belum bersedia sepenuhnya. Berdasarkan hujah di atas, kajian ini dilihat penting bagi mengenalpasti di samping untuk menilai sejauh mana prinsip-prinsip yang terkandung di dalam konsep pembangunan mapan diamalkan di kalangan komuniti Orang Asli serta bagaimana ilmu pengetahuan dan amalan mereka ini dapat digunakan untuk memandu arah pembentukan kerangka strategi pembangunan mapan komuniti tersebut pada masa yang akan datang.

\section{INDIKATOR KOMUNITI MAPAN}

Terdapat beberapa literatur yang menyentuh berkenaan pembangunan indikator komuniti mapan (lihat Copus dan Crebtree, 1996; Peterson, 1997; Jackson dan Robert, 2000; Yuan et al., 2003). Namun setelah diadakan perbincangan bersama-sama pakar di bidang tersebut serta penilaian terhadap kesesuaian setiap indikator yang ingin dipilih dengan keperluan kajian, pengkaji telah memilih dan menyenarai pendek sebanyak 45 indikator yang sesuai digunapakai untuk kajian ini. Indikator tersebut merangkumi dimensi ekonomi, sosial dan fizikal/alam sekitar serta dikategorikan kepada 3 komponen iaitu sikap, sistem dan situasi (Jadual 2).

Jadual 2: Cadangan indikator komuniti mapan

\begin{tabular}{|c|c|c|c|c|c|c|}
\hline Komponen & & & & & & $\begin{array}{l}\text { tor } \\
\text { Alam } \\
\text { ir }\end{array}$ \\
\hline Sikap & $\begin{array}{l}(1) \\
(12) \\
(15) \\
(16)\end{array}$ & & $\begin{array}{l}(2) \\
\text { (3) } \\
(4) \\
\text { (5) }\end{array}$ & $\begin{array}{l}(6) \\
(7) \\
(14)\end{array}$ & $\begin{array}{l}(8) \\
(9) \\
(10) \\
(11)\end{array}$ & (13) \\
\hline Sistem & $\begin{array}{l}(36) \\
(37) \\
(38)\end{array}$ & $\begin{array}{l}(39) \\
(40) \\
(41) \\
\end{array}$ & $\begin{array}{l}(42) \\
(43) \\
(44)\end{array}$ & & (45) & \\
\hline
\end{tabular}




\begin{tabular}{|c|c|c|c|c|}
\hline Situasi & $\begin{array}{l}(17) \\
(18) \\
(19) \\
(25) \\
(26) \\
(30)\end{array}$ & $\begin{array}{l}(20) \\
(21) \\
(22) \\
(23) \\
(24) \\
(27)\end{array}$ & $\begin{array}{l}(28) \\
(29) \\
(31)\end{array}$ & $\begin{array}{l}(32) \\
(33) \\
(34) \\
(35)\end{array}$ \\
\hline & & & & \\
\hline
\end{tabular}

\section{Indikator-indikator:}

1) Menyimpan wang

2) Bersukan

3) Merokok

4) Aktiviti kebudayaan

5) Bergotong-royong

6) Berpersatuan

7) Rancangan pembangunan komuniti

8) Penggunaan kimia dalam pertanian

9) Amalan guna semula

10) Amalan mengurangkan penggunaan

11) Amalan merawat/membaikpulih

12) Mengoptimumkan penggunaan halaman

13) Menjaga kebersihan halaman

14) Kesanggupan membantu jiran

15) Pekerjaan sampingan

16) Penglibatan ahli keluarga dalam pekerjaan

17) Kadar pengangguran

18) Pemilikan tanah

19) Mengusahakan tanah secara ekonomik

20) Aksess kepada khidmat kesihatan

21) Kadar jenayah
22) Kadar masalah sosial

23) Kadar penceraian

24) Pemilikan rumah dan infrastruktur

25) Purata pendapatan bulanan isirumah

26) Jumlah simpanan wang

27) Penerimaan pendidikan

28) Keadaan celik huruf

29) Kadar keciciran pelajaran

30) Kadar pergantungan ekonomi

31) Purata saiz isirumah

32) Kemudahan bekalan air

33) Kemudahan bekalan elektrik

34) Kemudahan tandas

35) Situasi pencemaran

36) Tempoh masa bekerja

37) Tahu-sistem pembahagian kerja

38) Amal - sistem pembahagian kerja

39) Tahu - sistem pembahagian hasil

40) Amal - sistem pembahagian hasil

41) Amal - perkongsian hasil

42) Kepatuhan undang-undang/adat

43) Terlibat sistem pembuatan keputusan

44) Pengasingan bilik anak lelaki-perempuan

45) Pengurusan sisa dan sampah

KAWASAN KAJIAN: KOMUNITI ORANG TEMIAR. KG. PERJEK DI RPS LEGAP DAN KG. KUALA MU, POS KUALA MU, KUALA KANGSAR, PERAK

Orang Temiar merupakan salah satu sukubangsa daripada kumpulan etnik Senoi, yang kebanyakannya ditemui di bahagian utara negeri Perak dan selatan negeri Kelantan. Sukubangsa ini mewakili kira-kira 16 peratus daripada populasi Orang Asli Semenanjung Malaysia. Di dalam kajian ini, dua perkampungan komuniti Temiar di daerah Kuala Kangsar telah dipilih iaitu Kg. 
Perjek di Rancangan Pengumpulan Semula (RPS) Legap, dan Kg. Kuala Mu di Pos Kuala Mu (Rajah 2).

Kg. Perjek merupakan salah sebuah kampung yang terletak di bawah RPS Legap yang mula dilaksanakan pada tahun 1982. Dengan keluasan tanah 44.6 hektar, kampung ini terdiri daripada 35 buah rumah, di mana 12 buah daripadanya merupakan rumah baru (binaan konkrit) yang diterima di bawah Program Perumahan bagi Rakyat Termiskin (PPRT). Seramai 187 orang mendiami perkampungan ini dengan 49 peratus lelaki dan 51 peratus perempuan. Kemudahan air di perkampungan ini dibekalkan melalui sistem paip air graviti dan bekalan elektrik pula dijana oleh sebuah generator petrol sumbangan Jabatan Kemajuan Islam Malaysia (JAKIM). Kemudahan sosial seperti sekolah rendah dan klinik kesihatan pula terdekat terletak di Pos Legap, kira-kira 2 kilometer dari situ. Aktiviti ekonomi tradisional berbentuk sara diri masih diamalkan sebahagian penduduk kampung terutama golongan tua dengan menanam padi bukit, pisang dan ubi kayu. Kebanyakan golongan dewasa dan anak belia pula memperoleh pendapatan melalui aktiviti penjualan buluh kasap dan menjadi buruh ladang sawit, iaitu skim pertanian yang diusahakan bersama JHEOA dan FELCRA negeri Perak merangkumi tanah seluas kira-kira 400 ekar.

Kg. Kuala Mu pula terletak lebih jauh ke dalam hutan kira-kira 30 kilometer dari Kg. Perjek. Skim pengumpulan semula yang dimulakan pada tahun 1974 ini telah mengumpulkan komuniti-komuniti kecil Orang Temiar yang sebelumnya hidup berselerak di sekitar kaki Gunung Korbu. Kampung ini mempunyai 34 buah rumah dan dihuni seramai 151 orang. Berbeza dengan $\mathrm{Kg}$. Perjek, rumah-rumah di $\mathrm{Kg}$. Kuala $\mathrm{Mu}$ adalah tradisional yang dibina sendiri oleh penduduk daripada buluh dan beratapkan daun bertam. Kampung ini telah dibekalkan sistem paip air graviti daripada sumber air sungai berdekatan dan bekalan elektrik pula diperoleh daripada unit-unit sistem solar individu. Namun, kebanyakan unit-unit solar ini telah rosak akibat tiada penyelenggaraan. Kebanyakan penduduk di kampung ini memperoleh pendapatan melalui jualan hasil hutan seperti rotan, herba, petai dan durian. Cuma sebilangan kecil (kirakira 18 peratus) isirumah yang bekerja sebagai pekebun kecil getah.

Pencapaian pendidikan formal di kedua-dua kampung dilihat masih berada pada paras yang rendah di mana hanya segelintir generasi muda menerima pendidikan sehingga tamat sekolah rendah. Walaupun kedua-dua kampung mempunyai sekolah yang berdekatan, namun untuk melanjutkan pelajaran ke peringkat sekolah menengah penduduk perlu menghantar anak-anak mereka ke sekolah menengah di Sungai Siput atau Ipoh. Kemiskinan dan keengganan 
Daripada jadual hasil analisis di atas didapati 9 daripada 16 indikator Sikap menunjukkan pencapaian tahap kemapanan yang tinggi. Indikator-indikator tersebut ialah penglibatan dalam pekerjaan sampingan (57.1\%), penglibatan ahli keluarga dalam pekerjaan (38.1\%), amalan gotong-royong $(90.5 \%)$, penglibatan dalam aktiviti kebudayaan (78.0\%), kesanggupan membantu jiran $(95.2 \%)$, penggunaan bahan kimia dalam pertanian $(0.0 \%)$, amalan guna semula $(71.4 \%)$, amalan mengurangkan penggunaan $(81.0 \%)$ dan kekerapan membersihkan halaman rumah $(52.4 \%)$. Di bawah komponen Sistem, hanya 2 daripada 10 indikator mencapai cadangan matlamat kemapanan iaitu indikator kepatuhan undang-undang/adat $(100.0 \%)$ dan amalan pengasingan bilik di antara anak lelaki dan perempuan (71.4\%). Bagi komponen Situasi pula, 7 daripada 19 indikator didapati mencapai cadangan matlamat kemapanan iaitu indikator kadar pengguran $(9.5 \%)$, pemilikan tanah $(77.8 \%)$, aksess kepada kemudahan kesihatan (100.0\%), pemilikan rumah sendiri (98.4\%), saiz isirumah yang sederhana $(38.1 \%)$, kemudahan bekalan air $(96.8 \%)$ dan tahap pencemaran $(7.9 \%)$.

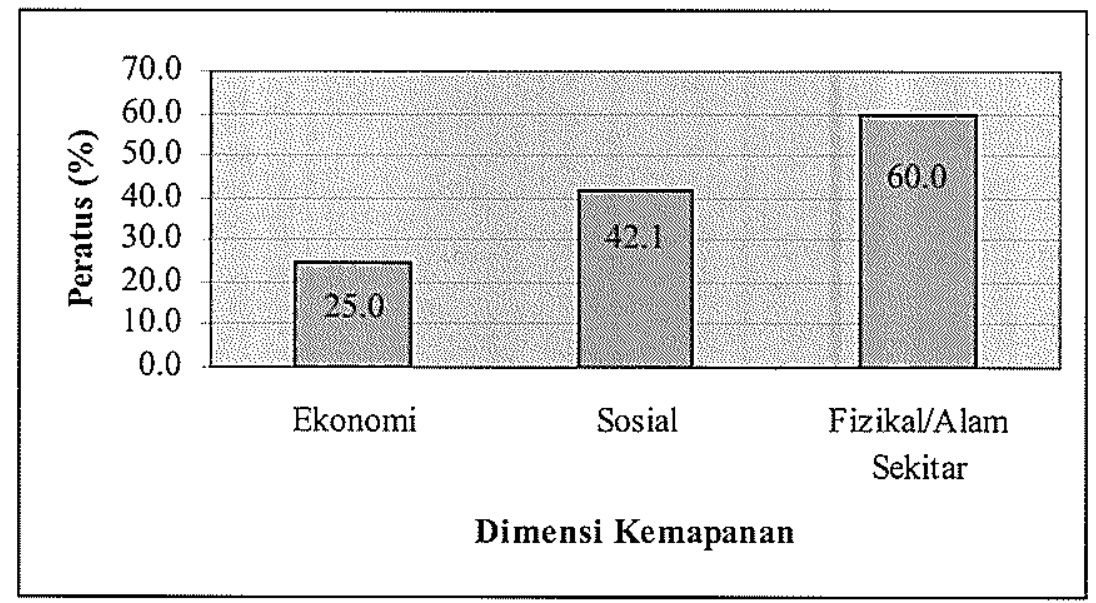

Rajah 3: Tahap kemapanan komuniti berpandukan dimensi kemapanan

Menggunakan kaedah pembahagian matematik ringkas bagi menentukan klasifikasi kemapanan ketiga-tiga dimensi kemapanan, nilai peratus $0-30 \%$ akan mewakili tahap kemapanan rendah; 31-60\% (tahap kemapanan sederhana) dan $61-100 \%$ (tahap kemapanan tinggi). Dengan perbandingan hasil analisis yang ditunjukkan pada Rajah 3, penulis merumuskan bahawa bagi dimensi kemapanan ekonomi dan sosial komuniti secara keseluruhannya berada pada tahap yang rendah $(25.0 \%$ dan $42.1 \%)$. Manakala dimensi fizikal dan alam sekitar pula menunjukkan tahap kemapanan sederhana $(60.0 \%)$, tetapi telah hampir kepada tahap kemapanan tinggi. 
Dapatan analisis ini secara langsung mengingatkan penulis agar memberi tumpuan yang lebih intensif semasa peringkat merancang kerangka strategi pembangunan mapan komuniti kelak. Kerangka strategi yang hendak dibentuk perlulah mengambilkira secara serius pelbagai aspek yang berkaitan pembangunan ekonomi yang maju dan berdaya saing, pembangunan modal insan dan pengupayaan penduduk untuk terbabit secara aktif dengan perancangan dan pembangunan komuniti serta menaiktaraf dan memperbaiki kualiti fizikal dan alam sekitar komuniti bagi kesejahteraan hidup.

Selain analisis data kuantitatif daripada borang soal-selidik, data-data kualitatif menggunakan pendekatan etnografi melalui penglibatan sebagai sebahagian peserta (partial-participant observation) dan temubual mendalam beberapa responden juga turut digunakan bagi menyokong hasil analisis kuantitatif, terutama untuk mengenalpasti permasalahan dan amalan tidak mapan di dalam komuniti yang memerlukan tindakan penyelesaian masalah pada masa hadapan.

\section{Aspek ketidakmapanan dalam komuniti}

Maklumat dan data hasil penglibatan sebagai sebahagian peserta, temubual mendalam ke atas responden serta sesi sumbang saranan bersama wakil penduduk, permasalahan-permasalahan dan aspek ketidakmapanan dalam komuniti telah dikenalpasti dan disenaraikan mengikut kategori-kategori sikap, sistem dan situasi di bawah dimensi ekonomi, sosial dan fizikal/alam sekitar sebagaimana ditunjukkan pada Jadual 4. Hasil analisis terhadap tahap kemapanan dan perbincangan bagi mengenalpasti kaedah penyelesaian terhadap permasalahan/ketidakmapanan komuniti membawa kepada pembentukan kerangka strategi pembangunan komuniti yang dihuraikan pada sub tajuk berikutnya.

Jadual 4: Permasalahan/Amalan tidak mapan di dalam komuniti

\begin{tabular}{|c|c|c|c|}
\hline $\begin{array}{l}\text { Komponen } \\
\text { Komuniti }\end{array}$ & Masalah Ekonomi & Masalah Sosial & $\begin{array}{c}\text { Masalah } \\
\text { Fizikal/Alam } \\
\text { Sekitar }\end{array}$ \\
\hline Sikap & $\begin{array}{l}\text { Tidak membuat } \\
\text { simpanan wang } \\
\text { Halaman rumah } \\
\text { tidak dimanfaat } \\
\text { untuk aktiviti } \\
\text { ekonomi }\end{array}$ & $\begin{array}{ll}\text { - } & \text { Tabiat merokok } \\
\text { - } & \text { Kurang } \\
\text { penglibatan } \\
\text { dalam aktiviti } \\
\text { sukan } \\
\text { - Kurang } \\
\text { penglibatan }\end{array}$ & $\begin{array}{l}\text { Aspek } \\
\text { pemulihan } \\
\text { sumber kurang } \\
\text { diberi penekanan }\end{array}$ \\
\hline
\end{tabular}




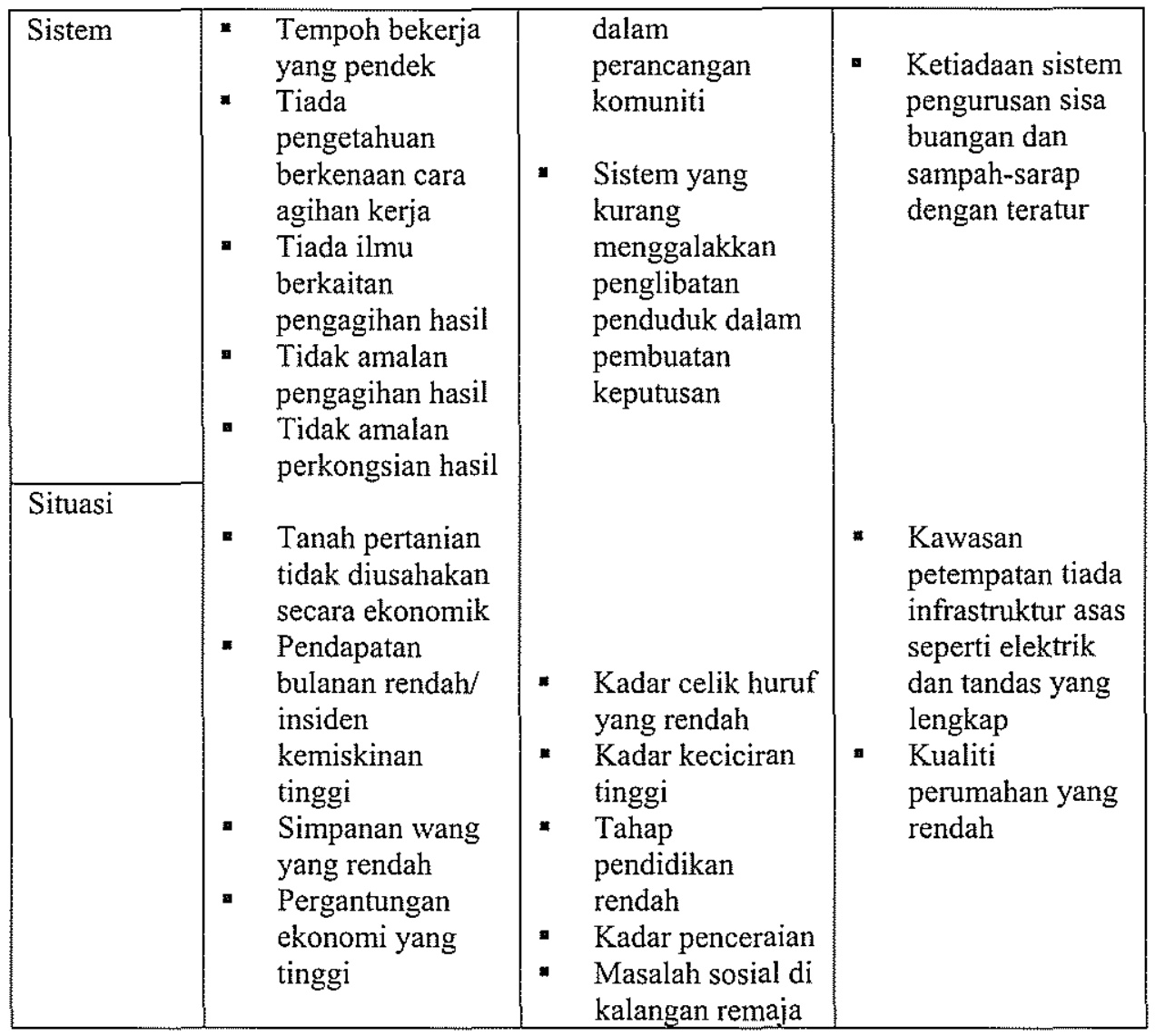

\section{Kerangka strategi pembangunan komuniti}

Cadangan kerangka strategi pembangunan mapan komuniti bagi kajian ini (rujuk Rajah 3) dibentuk setelah pengkaji mengambilkira cadangan konsep komuniti mapan dan hasil penilaian tahap kemapanan komuniti berdasarkan prestasi indikator-indikator. Pengkaji telah mengambilkira indikator yang menunjukkan tahap kemapanan tinggi (bertanda positif) sebagai potensi dan indikator yang menunjukkan tahap kemapanan rendah (bertanda negatif) sebagai masalah atau halangan yang perlu ditangani melalui pembentukan strategi pembangunan komuniti di masa yang akan datang. 
Pembangunan Komuniti Mapan - Konsep \& Indikator

\section{Komuniti}

Aktiviti Ekonomi Utama Komuniti

- Bertani tradisional/Pertanian pindah (ubi kayu, padi bukit)

- Bekerja buruh (ladang sawit dan getah, kerja kilang)

- Mencari dan menjual rotan dan buluh kasap

- Berniaga (secara runcit)

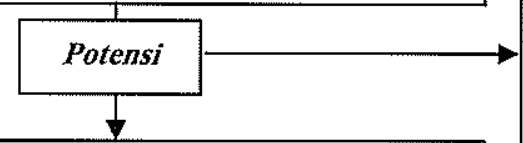

\section{Keunikan dan Potensi}

- Sumber manusia (kemahiran dalam pembuatan kraftangan, memburu, bertani dan mencari hasil hutan)

- Kedapatan tanah subur yang luas dan bersesuaian bagi menjalankan aktiviti pertanian (secara mesra alam dan berskala komersil)

- Seni dan budaya - keunikan cara hidup dan seni tradisional seperti upacara Sewang dan pembuatan barangan kraf

- Sumber alam semulajadi yang belum diteroka pembangunan seperti air terjun dan gunungganang, sesuai bagi aktiviti pelancongan ekologi

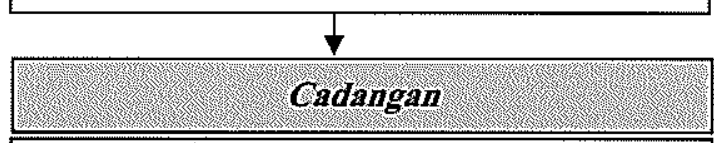

\section{Kerangka Strategi}

- Memelihara atau menggalakkan penerusan amalan-amalan sernasa yang mapan

- Mempertingkat/memperbaiki amalan-amalan semasa yang tidak mapan/menunjukkan tahap kemapanan yang rendah

- Membangunkan potensi sedia ada di kawasan kajian melalui perancangan dan tindakan yang mapan

\section{Praktis-Praktis Mapan}

Komponen Kemapanan Sikap

- Pekerjaan sampingan

- Penglibatan ahli keluarga dalam pekerjaan

- Penglibatan dalam aktiviti kebudayaan

- Penglibatan dalam gotongroyong

- Kesanggupan membantu jiran

- Penggunaan bahan kimia dalam pertanian

- Amalan guna semula

- Amalan mengurangkan penggunaan

- Amalan membersihkan halaman rumah

\section{Komponen Kemapanan Sistem}

- Kepatuhan kepada adat dan undang-undang

- Pengasingan bilik anak lelakiperempuan

\section{Komponen Kemapanan Situasi}

- Kadar pengangguran

- Pemilikan tanah

- Aksess kepada perkhidmatan kesihatan

- Pemilikan rumah

- Purata saiz isirumah

- Kemudahan bekalan air

- Kadar pencemaran

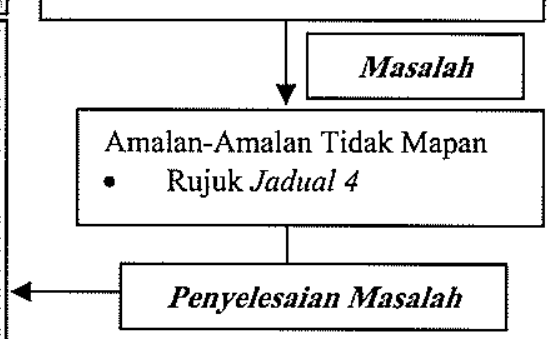




\section{KESIMPULAN}

Laluan yang dirintis ke arah pembentukan komuniti mapan memerlukan pemahaman yang terjurus tentang bagaimana pelbagai komponen dalam kehidupan komuniti yang kompleks dapat dihubung jalin secara seimbang sehingga menjadi satu unit yang mantap dan begitu melengkapi. Hasil kajian yang dibentangkan dalam artikel ini cuba membentuk kerangka pemahaman yang menyeluruh terhadap pembangunan mapan komuniti Orang Asli luar bandar. Ia termasuklah mengutarakan pandangan alternatif mengenai konsep komuniti mapan, mencadangkan set indikator kemapanan yang khusus bagi komuniti Orang Asli dan membentangkan kerangka pembentukan strategi pembangunan mapan bagi komuniti terlibat berdasarkan maklum balas analisis tahap kemapanan dan hasil sumbang saranan wakil komuniti terlibat. Sudah tiba masanya pihak-pihak yang terlibat dengan proses perancangan dan pembangunan komuniti luar bandar baik penggubal dasar, agensi dan badan pelaksana serta komuniti sasaran melihat dan memahami bahawa jalan ke arah membina komuniti yang mapan adalah begitu mencabar kerana ianya menuntut suatu strategi pembangunan yang tepat serta berkesan.

\section{RUJUKAN}

Copus A.K. and Crabtree J.R. 1996. Indicators of Socio-Economic Sustainability: An Application to Remote Rural Scotland, Journal of Rural Studies. Vol.12. pp. 41-54.

Dyer P., Aberdeen L. And Schuler S. 2003. Tourism Impacts on an Australian Indigenous Community. A Djabugay case study. Journal of Tourism Management. Vol.24. pp.83-95.

Earth Summit 1992. Earth Summit. London: The Regency Press.

Hjorth P. and Bagheri A. 2006. Navigating Towards Sustainable Development:

A system dynamics approach. Journal of Future. Vol.38. pp.74-92.

Ibrahim Ngah 2003. "Perancangan Komuniti Mapan: Apakah membina masa depan?" Kertas kerja pada Seminar Kebangsaan Perancangan Bandar \& Wilayah Ke-21, Universiti Teknologi Malaysia, Skudai.

Ibrahim Ngah dan Khairul Hisyam Kamarudin 2004. "Strategi Pembangunan Mampan Komuniti Orang Asli Luar Bandar". Kertas kerja pada Seminar Kebangsaan Perancangan Bandar \& Wilayah Ke-22, Universiti Teknologi Malaysia, Skudai.

Ibrahim Ngah and Khairul Hisyam Kamarudin 2005. "Sustainable Development of Orang Asli Community: A case study of Temiar Community". Paper presented in 1st International Conference on the Indigenous People 2005, 
The Indigenous Population: Survival of Modern Living. Kuala Lumpur. July 3-5 2005.

Jackson T. and Robert P. 2000. A Review of Indicators of Sustainable Development: A report for Scottish enterprise Tayside, Geddes Centre for Planning Research, School of Town Regional Planning, University of Dundee. www.trp.dundee.ac.uk.library/pubs/set.html.

Karjala M.K. and Dewhurst S.M. 2003. Including Aboriginal Issues in Forest Planning: A Case Study in Central Interior British Columbia, Canada. Journal of Landscape and Urban Planning. Vol.64. pp.1-17.

Loomis T.M. 2000. Indigenous Populations and Sustainable Development: Building on Indigenous Approaches to Holistic, Self-Determined Development. Journal of World Development. Vol.28. pp.893-910.

Moffatt I. 1996. Sustainable Development: Principles, Analisis and Policies. The Parthenon Publishing Group.

Musiiwa T. 2002. Sustainability, Indigenous Knowledge and Gender on Smallholder Irrigation Schemes in Manicaland, 1928-1997: Rethinking Peasant Agrarian History in Zimbabwe. Ph.D Thesis. The University of Minnesota.

Nicholas C. 2000. The Orang Asli and the Contest for Resources, Indigenous Politics, Development and Identity in Peninsular Malaysia. Copenhagen: IWGIA.

Peterson J.P. 1997. Indicators of Sustainable Development in Industrializing Countries. Vol.1. Management Response Strategies, Bangi: Penerbit UKM. Pulido J.S and Bocco G. (2003). The Traditional Farming System of a Mexican Indigenous Community: The case study of Nuevo San Juan Parangaricutiro, Michoacan, Mexico. Journal of Geoderma. Vol.111. pp.249-265.

Scott K.(2000). From Sustainable Rural Community to Social Sustainability:

Giving Voice to Diversity in Mangakahia Valley, New Zealand. Journal of Rural Studies. Vol.16. pp.433-446.

Yuan W., James P., Hodgson K., Hutchinson S.M. and Shi C. (2003). Development of Sustainability Indicators by Communities in China: A case study of Chongming, Shanghai. Journal of Environmental Management. Vol.68. pp. 253-261.

Zainuddin Muhammad 1996. "Planning Methods Towards Achieving Sustainable Community". Keynote Address. 15th EAROPH World Congress, Sustainable Communities. Auckland, New Zealand. 3-7 September 1996.

Zainuddin Muhammad 1997. "Perancangan Pembangunan Luar Bandar Mampan". Kertas kerja pada Seminar Kebangsaan Perancangan Bandar \& Wilayah Ke-21, Universiti Teknologi Malaysia, Skudai. 
